\title{
PENERAPAN WAREHOUSE MANAGEMENT SYSTEM PADA PT UNIPLASTINDO INTERBUANA BALI
}

\author{
I Gusti Ayu Putu Arika Putri ${ }^{1}$ \\ I Nyoman Nurcaya ${ }^{2}$ \\ ${ }^{1,2}$ Fakultas Ekonomi dan Bisnis Universitas Udayana (Unud), Bali, Indonesia \\ email: arikaputri28@gmail.com
}

\begin{abstract}
ABSTRAK
Warehouse Management System merupakan sistem aplikasi komputer berbasis database, yang digunakan untuk meningkatkan efisiensi gudang dalam menjaga keakuratan data persediaan dengan melakukan pencatatan setiap transaksi dalam gudang. Tujuan dari penelitian ini adalah untuk mengetahui adanya efisiensi biaya material handling yang ditimbulkan setelah dilakukan penerapan warehouse management system pada perusahaan. Penelitian dilakukan di PT Uniplastindo Interbuana Bali dengan simulasi penerapan warehouse management system. Berdasarkan perhitungan yang dilakukan, penerapan WMS mampu meningkatkan efisiensi biaya dan waktu dalam kegiatan material handling karena sistem mampu memberikan data penempatan material yang akurat. Data saat simulasi menunjukkan jumlah waktu yang lebih sedikit dibandingkan sebelum simulasi yang berarti biaya yang dikeluarkan lebih sedikit. Keberadaan sistem juga memberikan kemudahan admin terkait untuk mengumpulkan dan memperoleh data mengenai stock real di lapangan. Penyajian dan pengolahan data menjadi lebih cepat dan akurat sehingga dapat menimbulkan peningkatan kinerja pada perusahaan.
\end{abstract}

Kata kunci : Warehouse Management System (WMS), material handling, efisiensi biaya

\begin{abstract}
Warehouse Management System is a database-based computer application system, which used to improve warehouse efficiency in maintaining the accuracy of inventory data by recording every transaction in the warehouse. The purpose of this study was to determine efficiency of material handling costs incurred after implementation of warehouse management system. The research was conducted at PT Uniplastindo Interbuana Bali with simulation of implementation warehouse management system. Based on calculations, application of WMS able to increase cost efficiency and time efficiency in material handling because the system is able to provide accurate material placement data. Data during simulation shows a smaller amount of time compared to before simulation, which means less costs are incurred. Existence of system also makes it easy for related admin to collect data on real stock in the field. Data presentation and processing becomes faster and accurate so it can lead to increased performance in company.

Keywords: Warehouse Management System (WMS), material handling, cost efficiency
\end{abstract}




\section{PENDAHULUAN}

Persediaan merupakan salah satu faktor penting dalam kegiatan usaha dan ketersediaannya tidak dapat dihindarkan. Persediaan muncul karena barang-barang tersebut tidak dapat diperoleh secara instan, tetapi diperlukan tenggang waktu untuk memperolehnya. Persedian juga dapat timbulkan oleh tidak sinkronnya permintaan dengan penyediaan serta waktu yang digunakan untuk memproses bahan baku. Dengan adanya persediaan, maka perusahaan dapat memenuhi permintaan pelanggan dengan tepat waktu (Wahyudi, 2015)

Pengendalian sistem persediaan dengan tepat akan memudahkan perusahaan untuk menjalankan kegiatan operasional dan menjaga kelancaran siklus operasi perusahaan (Singh \& Singh, 2015). Pengorganisasian persediaan perlu dilakukan untuk menghindari ketidakefisienan kerja dan menciptakan keteraturan persediaan Dalam pengorganisasian persediaan diperlukan adanya sistem pengendalian dan pencatatan persediaaan karena akan berpengaruh terhadap proses produksi dan laporan keuangan perusahaan (Wambua et al., 2015). Sistem pengendalian dan pencatatan persediaan yang termasuk di dalamnya adalah terkait dengan jenis persediaan, jumlah persediaan, serta lokasi persediaan.

Sistem pengendalian dan pencatatan persediaan merupakan bagian dari manajemen pergudangan. Pelaksanaan manajemen ini merupakan proses dalam pengaturan barang yang masuk ke gudang dan barang yang keluar dari gudang. Proses ini dilakukan di gudang dengan suatu pencatatan administrasi tertentu (Kusuma dkk., 2017). Manajemen pergudangan dirancang untuk kepentingan pengolahan aktivitas pergudangan yang akan berpengaruh terhadap keseluruhan proses produksi. Manajemen pergudangan yang dikelola dengan baik akan mampu meningkatkan efisiensi penanganan bahan atau material handling dalam gudang (Azizi et al., 2018). Ditambah dengan kemajuan teknologi maka penanganan bahan dan persediaan dalam gudang akan semakin cepat dan praktis (Ogbo et al., 2014). Aktivitas manajemen pergudangan yang kompleks, akan sangat rumit apabila dilakukan secara manual. Dampak dari pencatatan secara manual adalah kemungkinan timbulnya informasi yang kurang berkualitas dan tidak tepat waktu sehingga menimbulkan penilaian yang bias terhadap persediaan (Chow et al., 2016). Kemajuan bidang teknologi menjadi solusi untuk mempermudah dalam mengakses dan mengontrol aktifitas pergudangan, yaitu dengan menggunakan suatu sistem pergudangan terkomputerisasi yang dinilai memiliki efektivitas pengerjaan dan akurasi dalam pengolahan datanya (Alyahya et al., 2016). Hal ini sejalan dengan penelitiaan Permadi \& Setya (2014), Makisurat dkk. (2014), Leopatria \& Palit (2013), Hakim dkk. (2017), Bagir \& Putro (2018), Kusuma (2017), Prabowo \& Pujotomo (2017), Pradana (2013), Mahendradipa (2013), Koster et al. (2017), Wood et al. (2015). Hasil penelitian tersebut menyatakan bahwa penerapan sistem pergudangan yang terkomputerisasi dapat meningkatkan efektifitas kerja operator gudang, akurasi data, memudahkan pencarian barang, pengolahan data lebih baik dan cepat, serta pencatatan dan penyimpanan persediaan yang lebih baik.

Sistem Manajemen Pergudangan atau Warehouse Management System (WMS) adalah suatu sistem aplikasi komputer berbasis database, yang digunakan untuk meningkatkan efisiensi gudang dalam menjaga keakuratan data persediaan 
dengan melakukan pencatatan setiap transaksi dalam gudang (Ramaa \& Rangaswamy, 2012). Warehouse Management System (WMS) berperan sebagai sistem yang mengatur kegiatan pergudangan dalam supply chain, seperti menerima stok, menyimpan stok dan mengatur order keluar stok (Wiyono dkk., 2011). Tujuan dari sistem ini adalah mengontrol pergerakan dan penyimpanan persediaan dalam sebuah gudang dan memproses transaksi terkait dengan penerimaan, pemilihan, pengambilan dan pengiriman persediaan dalam gudang. (Faber, 2013)

Sistem ini dikembangkan untuk memenuhi kebutuhan user agar lebih efisien dari sistem yang dilakukan secara manual (Tamas et al., 2017). WMS menjadi sebuah sistem yang relevan digunakan saat ini dibandingkan dengan pengoperasian gudang yang dilakukan secara manual untuk meningkatkan efisiensi dan pemenuhan pesanan secara optimal (Lee et al., 2017). Hal tersebut juga didukung oleh penelitian Scavarda et al (2012), Gomes et al. (2016), Al-Shakarchy \& Noor (2015), Prayodya \& Rinawati (2017) yang menyatakan bahwa penerapan Warehouse Management System dapat memudahkan sistem pergudangan dengan meningkatkan efisiensi dalam hal pencatatan dan pemrosesan data, meningkatkan keamanan data serta keakuratan data. Sistem ini juga dapat menjadi sebuah sarana bertukar informasi antar admin, user dan warehouse, apabila terjadi sebuah perubahan stok di dalam gudang akan dengan cepat dapat diketahui (Lukman \& Sunoto, 2016)

PT Uniplastindo Interbuana merupakan perusahaan manufakturing yang memproduksi kemasan minuman berbahan dasar plastik. Perusahaan yang memiliki kegiatan usaha utama yaitu mengolah bahan baku mentah dan bahan setengah jadi menjadi produk kemasan plastik berupa botol, cup (gelas plastik), dan botol 5 galon. Bahan yang digunakan dalam kegiatan produksi terdiri atas bahan baku utama (raw material) dan bahan pendamping (secondary material). Bahan baku utama yang digunakan dalam proses produksi yaitu bahan mentah berupa resin (bijih plastik), scrap (pecahan plastik) dan clariant (pewarna), serta bahan setengah jadi berupa preform. Bahan-bahan tersebut dibedakan kembali berdasarkan jenis, ukuran dan merek. Sedangkan bahan pendamping dalam proses produksi masuk dalam kategori pengemasan yaitu plastik inner, box dan lakban.

Seluruh persediaan bahan yang akan digunakan, disimpan dalam gudang bahan baku. Gudang pada PT Uniplastindo Interbuana terdiri atas gudang bahan baku dan gudang produk jadi. Penyimpanan serta pengambilan persediaan bahan dilakukan secara manual dengan bantuan forklift, hand pallet, serta tenaga manusia (karyawan).

Observasi dan wawancara dilakukan dengan operator gudang dan admin untuk mengetahui gambaran serta kondisi pengelolaan gudang saat ini. Bahan baku dari supplier yang sampai di gudang didata dan dihitung kembali secara manual oleh operator gudang dengan bantuan lampiran form persediaan. Hasil pencatatan dari form persediaan tersebut kemudian diinput manual oleh admin menggunakan software Ms. Excel. Sistem yang sama juga dilakukan ketika pengambilan bahan baku dari gudang untuk didistribusikan ke bagian produksi, pengurangan persediaan dilakukan secara manual. Kondisi ini sering menimbulkan permasalahan seperti ketidakakuratan data, kesalahan penginputan data, kehilangan data dan kurangnya integrasi data antara bagian admin kantor dengan operator 
gudang terkait dengan stok. Hal tersebut pada akhirnya menyebabkan ketidakefisienan kerja serta biaya dalam hal material handling.

Permasalahan yang kemudian dihadapi oleh perusahaan PT Uniplastindo Interbuana Bali saat ini adalah belum tersediannya sistem yang terkomputerisasi untuk menangani persediaan bahan di dalam gudang guna meningkatkan efisiensi kerja. Salah satu dampak yang ditimbulkan adalah operator gudang yang menangani pengambilan material untuk dikirimkan ke bagian produksi mengalami kendala dalam menentukan lokasi jenis material. Kondisi gudang yang luas dan jumlah material dengan jenis yang beragam bertumpuk-tumpuk, menyebabkan operator banyak kehilangan waktu dalam pengambilan material yang dibutuhkan karena harus mengindentifikasi satu per satu. Hal ini dapat menghambat pekerjaan dan membuat banyak waktu terbuang dalam pencarian material. Salah satu upaya yang dapat dilakukan oleh PT Uniplastindo Interbuana Bali untuk memperbaiki kinerja bagian pergudangan bahan baku adalah dengan menerapkan Sistem Manajemen Pergudangan (Warehouse Management System).

Penerapan sistem warehousing dengan fitur-fitur yang dibutuhkan oleh bagian pergudangan salah satunya yaitu lokasi penempatan material. Hal ini ditujukan untuk memudahkan operator dalam menemukan lokasi penyimpanan material yang dibutuhkan serta menciptakan sistem pergudangan yang lebih efisien sehingga dapat meminimalkan biaya material handling.

Berdasarkan latar belakang masalah yang telah diuraikan, maka dapat dirumuskan masalah pada penelitian ini yaitu apakah warehouse management system yang diterapkan pada PT Uniplastindo Interbuana Bali dapat meningkatkan efisiensi pada biaya material handling?

Berdasarkan latar belakang dan rumusan masalah, maka yang menjadi tujuan dalam penelitian ini yaitu untuk mengetahui apakah warehouse management system yang diterapkan pada PT Uniplastindo Interbuana Bali dapat meningkatkan efisiensi biaya material handling.

Hasil penelitian ini diharapkan mampu digunakan sebagai kajian maupun referensi bagi penelitian mendatang sehingga dapat menambah wawasan serta pemahaman khususnya mengenai warehouse management system. Hasil penelitian ini diharapkan dapat bermanfaat bagi PT Uniplastindo Interbuana Bali sebagai dasar untuk pengambilan keputusan dalam pemanfaatan warehouse management system.

Pada penelitian ini akan dilakukan pengamatan terhadap biaya material handling dalam sistem pergudangan yang diterapkan oleh perusahaan. Pengamatan dilakukan dengan mengadakan sebuah simulasi penerapan warehouse management system. Simulasi dengan menerapkan suatu sistem pergudangan sederhana berupa sebuah aplikasi database. Simulasi dilakukan di gudang bahan baku dengan mencoba menerapkan aplikasi database untuk pencatatan material saat penerimaan dan pengiriman material. Data dikumpulkan saat sebelum simulasi dan saat simulasi dilakukan dengan menggunakan sistem aplikasi database. Hal ini dilakukan untuk memperbandingkan data dan untuk mengetahui penerapan warehouse management system dapat meningkatkan efisiensi atau tidak.

Pengumpulan data dilakukan dengan menghitung waktu yang diperlukan untuk melakukan perpindahaan material serta jarak yang ditempuh selama 
penerimaan dan pengiriman material. Waktu dan jarak yang dihitung kemudian akan dikonversikan kedalam biaya dengan perhitungan. Biaya tersebut yang kemudian akan diperbandingkan untuk mengetahui besaran efisiensi yang ditimbulkan. Berikut ini adalah gambaran kerangka konseptual.

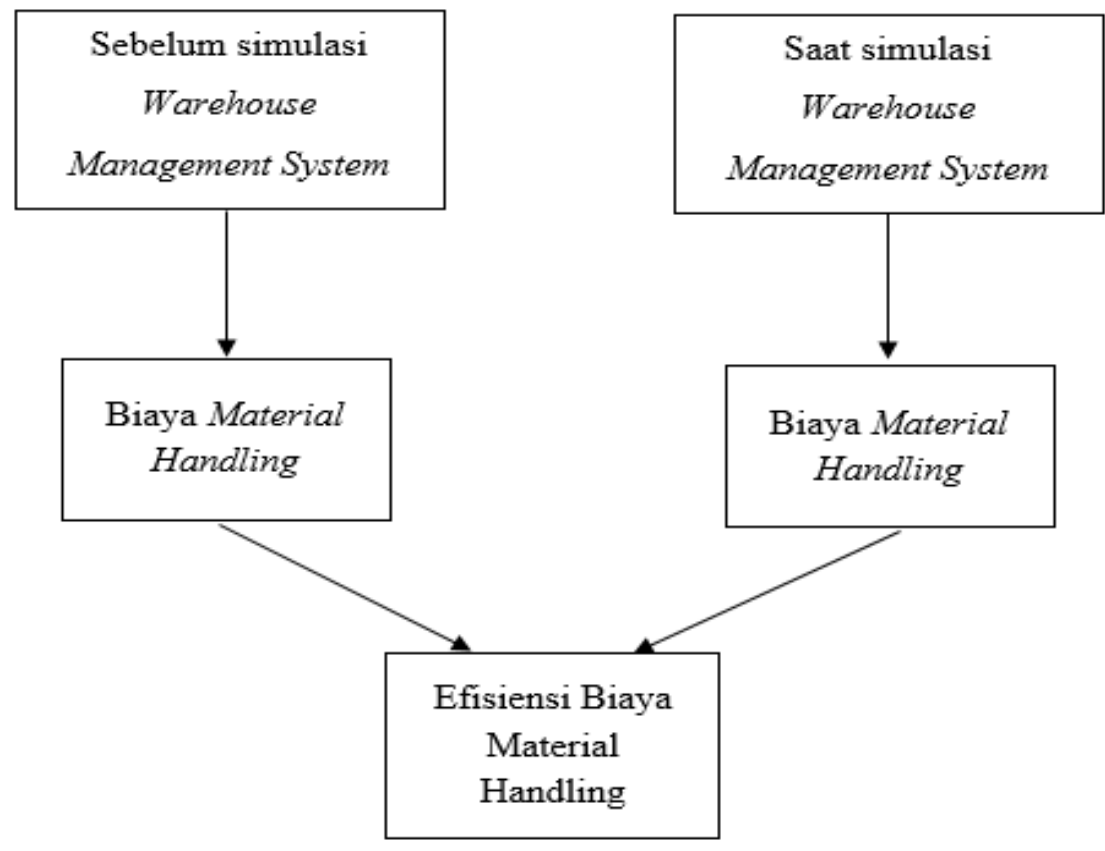

Gambar 1. Kerangka Konseptual Penelitian

\section{METODE PENELITIAN}

Desain penelitian yang digunakan dalam penelitian ini adalah berbentuk deskriptif komparatif. Penelitian ini merupakan studi kasus yang dilakukan dengan cara membandingkan biaya material handling sebelum dan saat penerapan warehouse management system pada PT Uniplastindo Interbuana Bali dengan harapan adanya efisiensi yang ditunjukan dalam proses material handling.

Penelitian ini dilakukan di PT Uniplastindo Interbuana Bali, sebuah perusahaan manufakturing yang bergerak di bidang industri kemasan minuman berbahan dasar plastik yang berlokasi di Jalan Raya Gilimanuk Denpasar Km. 26, Desa Sembung Gede, Tabanan, Bali. Perusahaan ini dipilih karena masih menggunakan sistem manual dalam pergudangan dan pengorganisasian persediaan.

Objek yang digunakan dalam penelitian ini adalah material handling dalam gudang bahan baku di PT Uniplastindo Interbuana Bali dengan fokus penerimaan dan pengiriman bahan baku (raw material) untuk material preform.

Variabel merupakan objek penelitian atau sesuatu yang menjadi titik perhatian dalam suatu penelitian. Variabel yang digunakan dalam penelitian ini yaitu Material Handling.

Material handling adalah salah satu jenis transportasi (pengangkutan) yang dilakukan dalam perusahaan industri, yang artinya memindahkan bahan baku, barang setengah jadi atau barang jadi dari tempat asal ketempat tujuan yang telah 
ditetapkan. Biaya material handling adalah biaya yang dikeluarkan untuk melakukan pemindahan material dari satu departemen menuju departemen yang lain untuk dilakukannya proses produksi selanjutnya, yang akan dianalisi melalui frekuensi perpindahan, ongkos material handling $(\mathrm{OMH})$, dan jarak antar fasilitas (Maheswari \& Dany, 2015)

Data kualitatif yang digunakan dalam penelitian ini adalah data yang diperoleh melalui wawancara dan observasi yaitu seperti informasi mengenai gambaran umum perusahaan, jenis persediaan bahan baku, material handling dan sistem pergudangan yang diterapkan.

Data kuantitatif yang digunakan dalam penelitian ini adalah data mengenai jumlah produksi, jumlah persediaan bahan, jumlah penerimaan dan pengeluaran bahan baku di gudang, serta biaya yang terkait dengan sistem pergudangan.

Sumber primer dalam penelitian ini diperoleh melalui observasi dan wawancara dengan pihak perusahaan PT Uniplastindo Interbuana Bali yaitu dengan manajer perusahaan, staff serta bagian pergudangan mengenai sistem pergudangan yang telah diterapkan oleh perusahaan.

Sumber sekunder dalam penelitian ini diperoleh dari data perusahaan, bukubuku referensi dan bahan pustaka lainnya yang berkaitan dengan kebutuhan penelitian.

Metode pengumpulan data yang dilakukan dalam penelitian ini adalah metode observasi, wawancara dan simulasi sistem warehousing. Observasi yang dilakukan yaitu terkait dengan sistem pergudangan perusahaan, sistem persediaan, dan proses penyimpanan dan pengambilan produk di gudang. Selanjutnya observasi terhadap data historis perusahaan yang mencakup jumlah produksi, jumlah penerimaan dan pengeluaran barang di gudang. Wawancara pada bagian gudang dan produksi terkait dengan sistem pergudangan.

Simulasi penerapan warehouse management system dilakukan di gudang bahan baku saat penerimaan dan pengiriman material. Data dikumpulkan saat sebelum simulasi dan saat simulasi dilakukan dengan menghitung waktu yang diperlukan untuk melakukan perpindahaan material baik saat penerimaan maupun pengiriman material. Waktu yang dihitung kemudian akan dikonversikan kedalam biaya dengan perhitungan. Biaya tersebut yang kemudian akan diperbandingkan untuk mengetahui besaran efisiensi yang ditimbulkan.

\section{HASIL DAN PEMBAHASAN}

PT Uniplastindo Interbuana merupakan perusahaan manufakturing yang memproduksi kemasan makanan dan minuman berbahan dasar plastik. PT Uniplastindo Interbuana didirikan pada tahun 1993 oleh sekelompok ahli teknik yang bertujuan untuk membantu meningkatkan standar pembuatan kemasan produk dengan metode yang efektif di Indonesia. Pabrik pertama didirikan pada tahun 1995 dan Uniplast mulai memproduksi produk Cup. Pada tahun 2001, Uniplast menambah variasi produk dengan memproduksi Botol 5 Galon. Tahun 2003, pabrik kedua didirikan dengan produksi berupa Preform dan Botol. Selanjutnya di tahun 2004 Uniplast bereskpansi dan melakukan produksi in-plant, kemudian selanjutnya perusahaan mulai memproduksi Tutup Botol. Pada tahun 2007, Uniplast menjadi perusahaan produsen kemasan pertama di Indonesia yang mendapatan akreditasi 
ISO 22000. Saat ini Uniplast telah mengoperasikan 11 pabrik, termasuk lokasi inplant dan salah satunya yaitu PT Uniplastindo Interbuana Bali.

Sistem atau model produksi yang dijalankan oleh perusahaan adalah model produksi pull. Model produksi pull adalah model produksi yang hanya melakukan proses produksi secara menarik yaitu barang yang diproduksi didasarkan pada permintaan sales (sales order). Seluruh customer dari perusahaan yaitu PT Tirta Investama (Aqua Danone), PT Balian Waters, PT Tirta Bali Sejahtera akan memberikan jumlah permintaan berupa forcasting (perkiraan) dan mengeluarkan jumlah order setiap beberapa periode. PT Tirta Investama merupakan customer utama perusahaan, jumlah permintaan produk akan dikeluarkan setiap satu minggu sekali. Jumlah produksi akan lebih banyak untuk memenuhi kebutuhan dari PT TIV karena jumlah orderan cenderung stabil. Berbeda dengan 2 customer lainnya, yaitu botol Balian dan Aguri, periode produksi berkisar antara 3-6 bulan sekali. Hal tersebut dikarenakan jumlah permintaan yang tidak menentu dan jumlah yang tidak terlalu banyak.

Kegiatan produksi perusahaan menggunakan 6 mesin yang berbeda yaitu mesin Illig untuk produksi Cup, mesin Kosme 1, Kosme 2, Kosme 3 dan Sidel untuk produksi Botol serta mesin Automa untuk produksi Botol 5 Galon. Proses produksi berlangsung setiap hari dengan 3 pembagian shift kerja selama 24 jam. Hasil output produksi bulan Januari hingga November 2018 terlampir dalam Lampiran 1. Berikut merupakan rangkuman hasil output produksi bulan Januari hingga November 2018 per-triwulan dalam setiap jenis item ditunjukkan dalam Tabel berikut.

Tabel 1.

Hasil Produksi PT Uniplastindo Interbuana Bali selama Tahun 2018 (dalam pes)

\begin{tabular}{|c|c|c|c|c|}
\hline \multirow[b]{2}{*}{ Jenis Output } & \multicolumn{4}{|c|}{ Jumlah Output } \\
\hline & $\begin{array}{l}\text { Triwulan I } \\
\text { (Jan-Mar) }\end{array}$ & $\begin{array}{l}\text { Triwulan II } \\
\text { (Apr-Jun) }\end{array}$ & $\begin{array}{l}\text { Triwulan III } \\
\text { (Jul-Sep) }\end{array}$ & $\begin{array}{c}\text { Triwulan IV } \\
\text { (Okt-Nov) }\end{array}$ \\
\hline Cup Aqua $220 \mathrm{ml}$ & 66.186 .712 & 71.712 .763 & 75.464 .876 & 51.054 .832 \\
\hline $\begin{array}{l}600 \mathrm{ml} \\
\text { Botol Aqua Anggun }\end{array}$ & 5.214 .052 & 6.551 .710 & 7.940 .647 & 6.461 .631 \\
\hline $\begin{array}{l}1500 \mathrm{ml} \\
\text { Botol } 5 \text { Galon Aqua }\end{array}$ & $\begin{array}{l}3.510 .037 \\
160.581\end{array}$ & $\begin{array}{l}6.114 .652 \\
77.063\end{array}$ & $\begin{array}{c}5.226 .079 \\
176.007\end{array}$ & $\begin{array}{r}4.999 .450 \\
107.969\end{array}$ \\
\hline $\begin{array}{l}\text { Botol } 5 \text { Galon Aguri } \\
\text { Botol Balian } 330 \mathrm{ml} \\
\text { Botol Balian } 500 \mathrm{ml}\end{array}$ & $\begin{array}{c}- \\
- \\
22.935\end{array}$ & $\begin{array}{c}9.196 \\
436.426\end{array}$ & 1.242 .901 & $\begin{array}{c}- \\
152.402 \\
165.231\end{array}$ \\
\hline
\end{tabular}

Bahan baku yang digunakan untuk proses produksi terdiri atas bahan baku utama (raw material) dan bahan pendamping (secondary material). Bahan baku utama yang digunakan untuk proses produksi terdapat beragam jenisnya. Proses produksi cup menggunakan bahan berupa resin PP (polypropylene) Trilene dan scrap PP (polypropylene). Produksi botol menggunakan material preform yaitu preform 14 gr untuk botol Aqua $600 \mathrm{ml}$, preform 27,5 gr untuk botol Aqua 1500 $\mathrm{ml}$, preform 17 gr untuk botol Balian $330 \mathrm{ml}$ dan preform 25,03 gr untuk botol Balian $500 \mathrm{ml}$. Preform juga dibagi kedalam beberapa jenis berdasarkan bahan 
baku pembuatanya yang dibedakan berdasarkan merek yaitu preform Ramapet N2, TLE 105, SA 135, dan CZ 302. Produksi botol 5 galon menggunakan bahan resin PC (polycarbonate) Novarex dan scrap PC (polycarbonate).

Bahan pendamping yang digunakan dalam proses produksi yaitu berupa bahan untuk pengemasan produk hasil produksi. Bahan-bahan tersebut yaitu plastik inner ukuran 145 untuk plastik inner cup, $175 \mathrm{~cm}$ untuk plastik inner botol, dan 200 untuk plastik cover nictainer (kontainer untuk cup), carton box untuk botol dan carton seal (lakban) 1 inch dan 2 inch.

Tabel 2.

Penggunaan Bahan Baku Preform dalam Proses Produksi selama Bulan Januari-November 2018

\begin{tabular}{|c|c|c|c|c|}
\hline \multirow[b]{2}{*}{ Jenis Bahan Baku } & \multicolumn{4}{|c|}{ Jumlah Penggunaan Bahan Baku } \\
\hline & $\begin{array}{l}\text { Triwulan I } \\
\text { (Jan-Mar) }\end{array}$ & $\begin{array}{l}\text { Triwulan II } \\
\text { (Apr-Jun) }\end{array}$ & $\begin{array}{l}\text { Triwulan III } \\
\text { (Jul-Sep) }\end{array}$ & $\begin{array}{c}\text { Triwulan IV } \\
\text { (Okt-Nov) }\end{array}$ \\
\hline Preform 14gr Ramapet & & & & \\
\hline N2 (pes) & 3.704 .388 & 2.124 .165 & 4.870 .240 & 5.858 .402 \\
\hline $\begin{array}{l}\text { Preform 14gr CZ } 302 \\
\text { (pes) }\end{array}$ & 201.106 & 3.914 .744 & 835.121 & 1.070 .112 \\
\hline $\begin{array}{l}\text { Preform 14gr TLE } 105 \\
\text { (pes) }\end{array}$ & - & 216.846 & - & - \\
\hline $\begin{array}{lcc}\text { Preform } 27,5 & \mathrm{gr} \\
\text { Ramanet N2 (pcs) }\end{array}$ & 115507 & 982507 & 6588666 & - \\
\hline $\begin{array}{l}\text { Preform 27,5 gr CZ302 } \\
\text { (pes) }\end{array}$ & 2.493 .943 & 4.645 .231 & 2.051 .882 & 3.230 .801 \\
\hline $\begin{array}{l}\text { Preform 27,5 gr TLE } \\
105 \text { (pcs) }\end{array}$ & 2.105 .920 & 1.139 .782 & 177.030 & 1.301 .766 \\
\hline 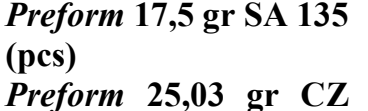 & - & 17.190 & - & 152.402 \\
\hline 302 (pes) & 22.935 & - & - & 165.231 \\
\hline Resin PP Trilene (kg) & 171.475 .000 & 240.825 .000 & 249.275 .000 & 169.100 .000 \\
\hline Resin PC Novarex (kg) & 48.843 .500 & 25.052 .000 & 47.475 .000 & 32.225 .000 \\
\hline
\end{tabular}

Gudang produk jadi dibagi menjadi tiga areal yaitu Gudang 2 sebagai tempat menyimpanan produk cup dan botol. Gudang 3 berada di areal produksi. Gudang ini berfungsi sebagai tempat transit produk botol dan botol 5 galon setelah diproduksi serta tempat transit untuk material sebelum masuk ke mesin produksi. Gudang 4 sebagai tempat penyimpanan produk botol dan gudang 5 sebagai tempat penyimpanan botol 5 galon serta persediaan box, pallet, scrap dan produk, material reject.

Area gudang 1 sebagai tempat penyimpanan bahan baku memiliki luas 704 $\mathrm{m}^{2}$. Gudang ini dibagi menjadi dua area yaitu area A dan area B. Area A memiliki kapasitas kolom sebanyak $13 \times 6$ dan diberi kode A1 sampai dengan A13. Area A1A4 digunakan untuk penyimpanan secondary material dan area A5-A13 digunakan untuk menyimpan raw material. Area B memiliki kapasitas kolom sebanyak $16 \mathrm{x}$ 9 dengan kode B1 sampai dengan B16 dan seluruhnya digunakan untuk tempat penyimpanan raw material. Berikut adalah gambar ilustrasi gudang 1 PT Uniplastindo Interbuana Bali. 


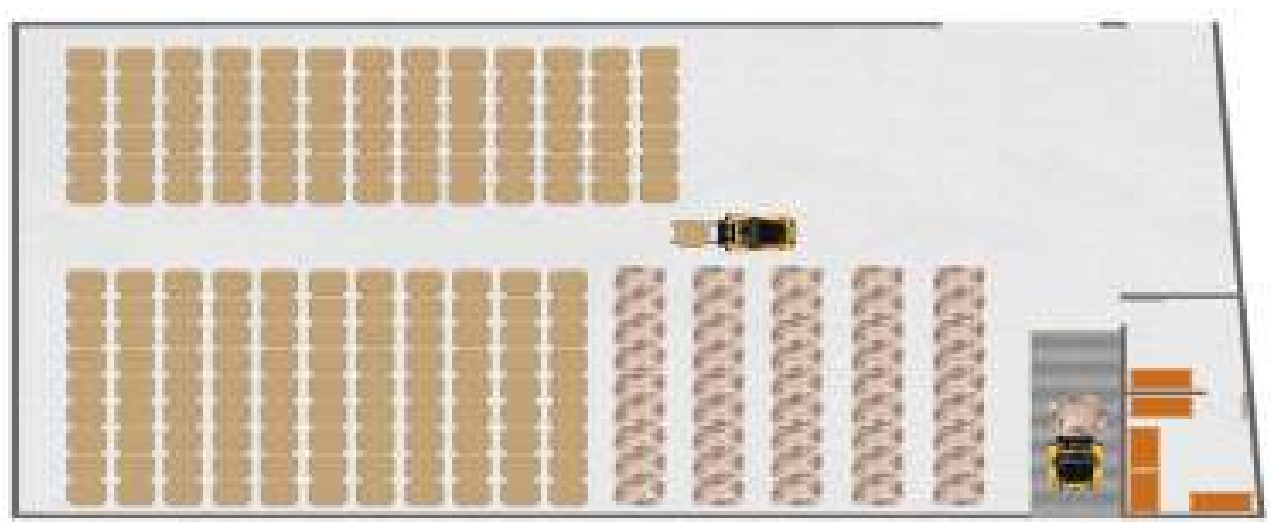

Gambar 2. Ilustrasi Tampak Atas Gudang Bahan Baku (Gudang 1) Sumber: PT Uniplastindo Interbuana Bali, 2018

Sistem pergudangan pada PT Uniplastindo Interbuana Bali ditangani oleh departemen PPIC (Product Planning and Inventory Control). Departemen PPIC terdiri atas Supervisor PPIC, admin PPIC, helper gudang dan operator forklift. Tugas dari departemen ini adalah merencanakan dan mengendalikan aliran bahanbahan yang masuk ke proses produksi, bahan/barang yang sedang dalam proses serta bahan/barang yang keluar dari pabrik agar tidak terjadi kekurangan atau kelebihan bahan dan proses produksi dapat berjalan dengan lancar.

Aliran bahan-bahan atau material mulai dari order material di supplier hingga material sampai pada proses produksi diatur oleh departemen PPIC.

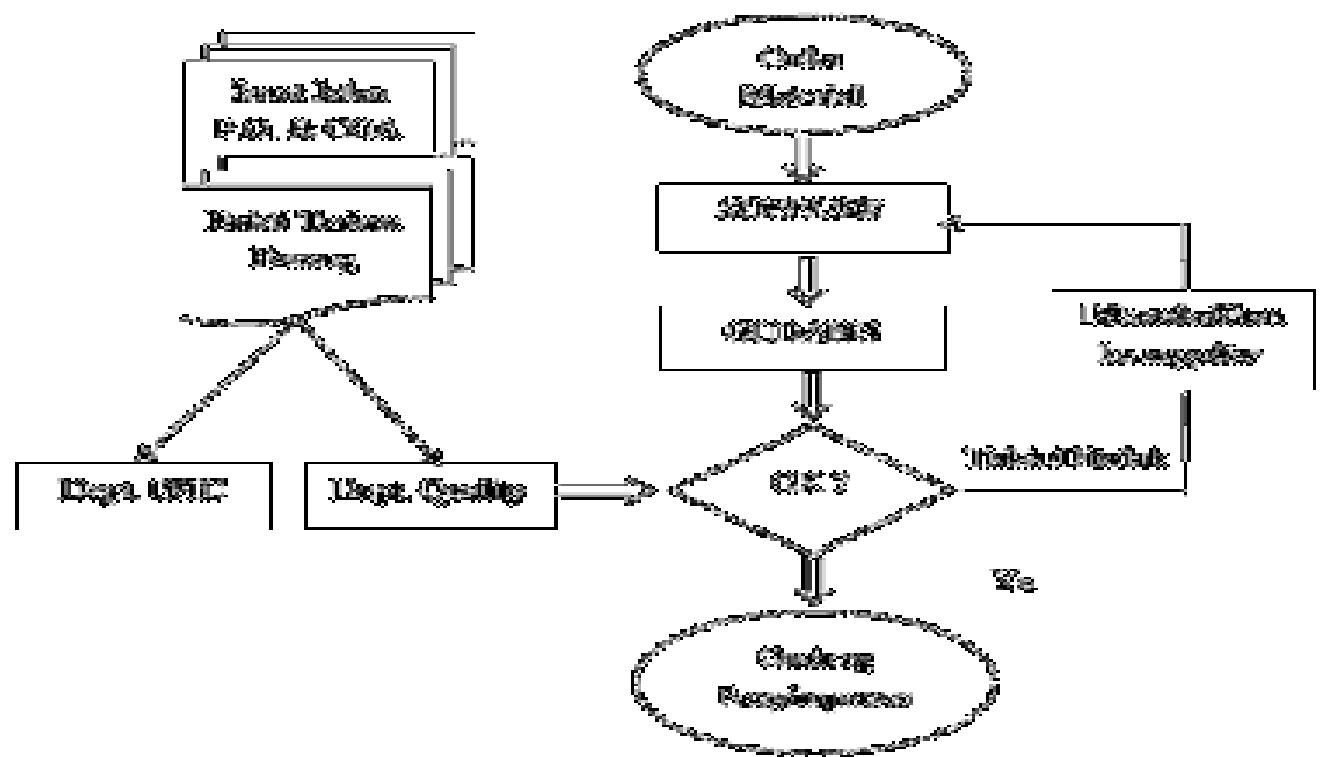

Gambar 3. Alur Penerimaan Material

Sumber : PT Uniplastindo Interbuana Bali, 2018

Alur penerimaan material dimulai dari admin PPIC yang melakukan order sesuai dengan kebutuhan kepada supplier/rekanan bahan masing-masing. Material yang telah diorder akan dikirimkan sesuai dengan Surat Jalan dan Purchase Order 
(P.O.) oleh supplier. Material yang telah sampai di pabrik Uniplast kemudian dibongkar oleh operator gudang dan dibantu oleh helper gudang. Validasi terhadap sampel material yang diterima dilakukan oleh departemen Quality Control untuk mengetahui kondisi material sesuai dengan CoA (Certificate of Analysist) dan kondisi fisik barang aktual saat diterima. Jika hasil validasi material baik maka proses bongkar akan dilanjutkan dan jika hasil validasi tidak baik (material reject) maka material akan dikembalikan (return) kepada supplier. Barang yang telah dibongkar dari kontainer akan diletakkan di gudang sesuai dengan jenisnya seperti preform, resin PP dan resin PC.

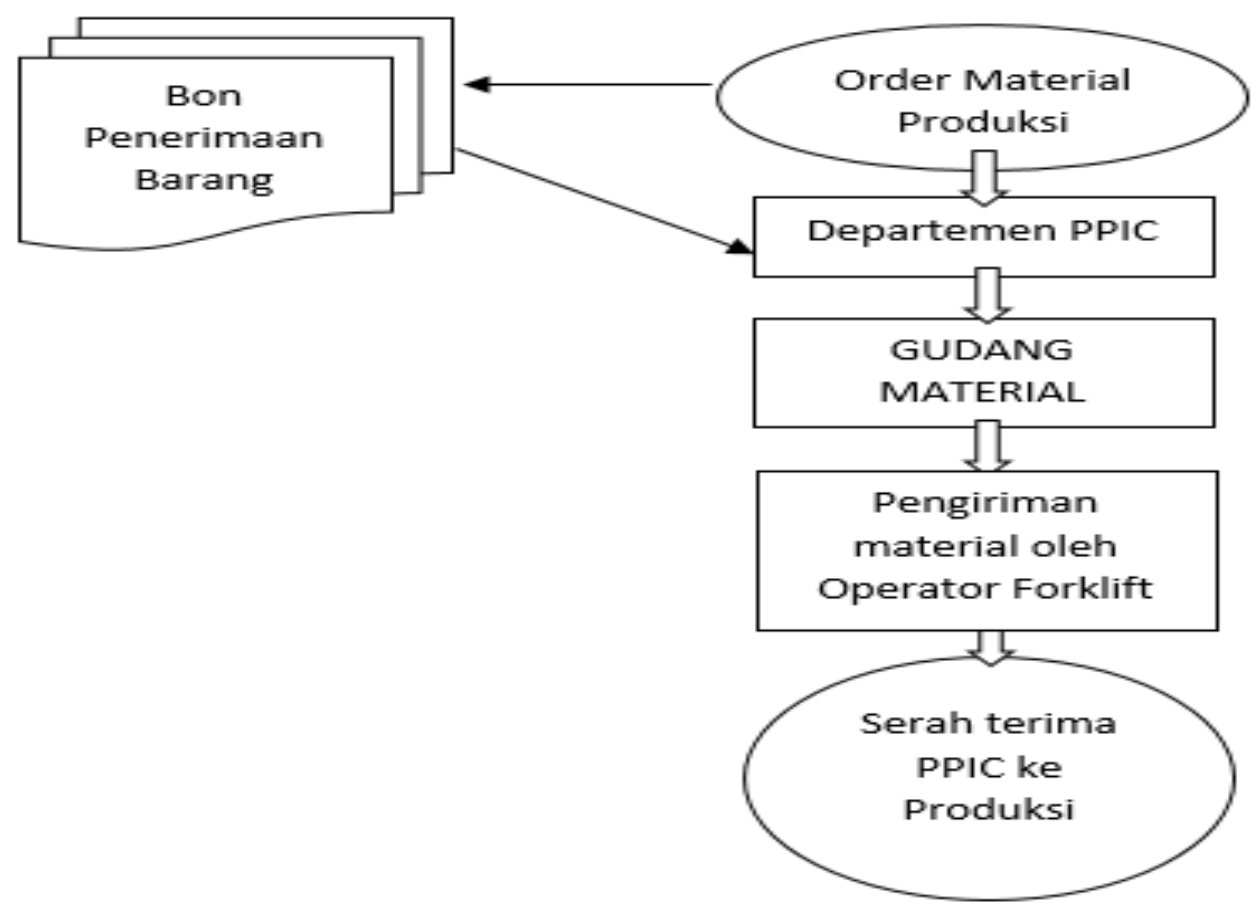

Gambar 4. Alur Pengiriman Material

Sumber: PT Uniplastindo Interbuana Bali, 2018

Alur pengiriman material dimulai dari admin produksi mengeluarkan Bon Penerimaan Barang (bon order material) sesuai dengan kebutuhan material setiap harinya. Bon order berisikan tanggal, nomor dokumen bon, jenis material serta jumlah yang dibutuhkan. Khususnya pesanan preform dapat berbeda-beda jenis tergantung pada setting produksi dan stok material di gudang penyimpanan. Bon tersebut diserahkan kepada admin PPIC kemudian material dipersiapkan sesuai dengan jenis dan jumlah yang dibutuhkan. Operator forklift akan mengirimkan barang dari gudang penyimpanan ke area produksi.

Proses pencatatan barang setalah penerimaan dan pengiriman material masih dilakukan secara manual yaitu dengan mencatat manual barang yang keluar dan masuk ke gudang material. Hal ini dilakukan untuk menghitung stock real di lapangan dan lokasi penempatannya. Sistem penilaian persediaan yang digunakan dalam perusahaan yaitu sistem FIFO (First In First Out). Dimana barang yang masuk pertama akan dikeluarkan pertama kali. Hal ini juga diterapkan dalam 
pengiriman material ke bagian produksi. Namun pada penerapannya sehari-hari sistem ini masih terkendala untuk dilakukan. Hal tersebut dikarenakan sulitnya menelusuri tanggal kedatangan barang serta lokasi spesifik terlebih saat kondisi gudang sedang full stock yang dapat mempersulit operator untuk mengambil bahan sesuai sistem FIFO.

Proses penerimaan dan pengiriman material yang dilakukan di dalam gudang menggunakan bantuan alat angkut yaitu forklift dan hand lift (hand pallet). Forklift yang digunakan oleh perusahaan dengan merek TCM dan berkapasitas 5 ton. Forklift tersebut menggunakan bahan bakar gas LPG agar terhindar dari polusi udara yang dapat mencemari areal produksi. Forklift dengan merek TCM memiliki kapasitas 5 ton dan harga beli sebesar Rp 275.000.000,00. Umur pemakaian saat ini yaitu 10 tahun dan umur ekonomis selama 25 tahun dengan nilai sisa (residu) sebesar Rp 8.000.000,00. Biaya pemeliharaan forklift yaitu Rp 725.400,00/bulan.

Hand pallet yaitu berupa kereta dorong manual yang digunakan untuk memindahkan barang dengan tenaga manusia. Alat ini digunakan ketika memindahkan barang dengan bobot yang terbilang ringan dan masih dalam kapasitas tenaga karyawan. Jumlah hand pallet yang dimiliki oleh karyawan adalah sebanyak empat buah. Hand pallet yang digunakan adalah merek Hippo dengan kapasitas $2500 \mathrm{~kg}$. Harga beli sebesar Rp 2.500.000,00. Umur saat ini yaitu 4 tahun dan umur ekonomis yaitu 8 tahun. Nilai sisa (residu) sebesar Rp 100.000,00 dan biaya pemeliharaan sebesar Rp 60.000/bulan.

Pada penerapannya di lapangan, untuk proses penerimaan material hand pallet hanya digunakan untuk menarik palet dari sisi dalam kontainer menuju sisi ujung luar kontainer. Hal itu dilakukan untuk memudahkan forklift mengangkat palet dari kontainer sehingga penggunaan hand pallet dalam proses material handling tidak begitu signifikan. Termasuk dalam proses pengiriman material, hand pallet digunakan pada saat pengiriman material untuk memasuki areal produksi yang susah dijangkau oleh forklift ketika kondisi gudang sedang penuh.

Simulasi yang dilakukan yaitu mencoba menerapan sistem warehousing sederhana dilakukan pada area gudang bahan baku PT Uniplastindo Interbuana Bali. Simulasi difokuskan pada kegiatan pengiriman dan penerimaan material Preform. Hal ini dilakukan karena proses pengiriman preform yang terbilang lebih mudah untuk diamati dibandingkan dengan material lainnya. Pengambilan data material handling sebelum simulasi dilakukan pada bulan Oktober 2018 selama 7 hari dan pelaksanaan simulasi dilakukan pada bulan November 2018 yang juga selama 7 hari.

Sistem sederhana yang digunakan dalam simulasi yaitu berupa software database Microsoft Access. Microsoft Access merupakan sebuah aplikasi yang digunakan untuk membuat basis data. Format original dari Microsoft Access adalah .mdb. Microsoft Access yang digunakan telah didesain sesuai dengan kebutuhan untuk dapat memudahkan penggunanya seperti operator dan admin PPIC.

Sistem database warehousing sederhana yang dirancang sesuai dengan kebutuhan pergudangan agar dapat menyimpan data persediaan yang ada di gudang, melakukan penginputan material masuk dan material yang keluar dari gudang. Sistem ini juga dirancang untuk dapat mengetahui keberadaan barang di dalam 
gudang. Hal ini bertujuan untuk memudahkan operator untuk mengambil dan meletakkan material. Berikut merupakan tampilan sistem yang akan disimulasikan.

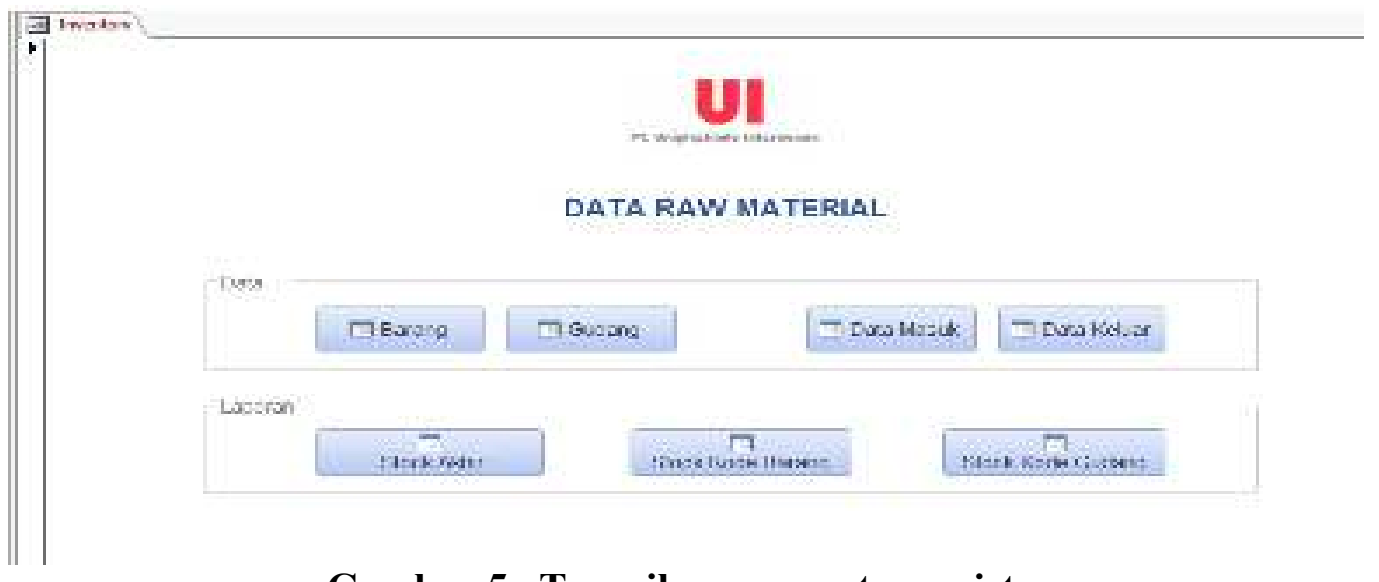

Gambar 5. Tampilan menu utama sistem

Gambar 5. menunjukkan tampilan menu utama dalam sistem. Beberapa fitur didalamnya yaitu menu barang, gudang, data masuk, data keluar, dan laporan stok akhir berupa menu stock akhir, stock kode barang, stock kode gudang.

Menu barang memuat data mengenai kode barang dan nama barang yang dalam hal ini merupakan material preform yang ada didalam gudang material. Seluruh jenis material preform berdasarkan ukuran dan jenisnya diinputkan dengan kode masing-masing jenis.

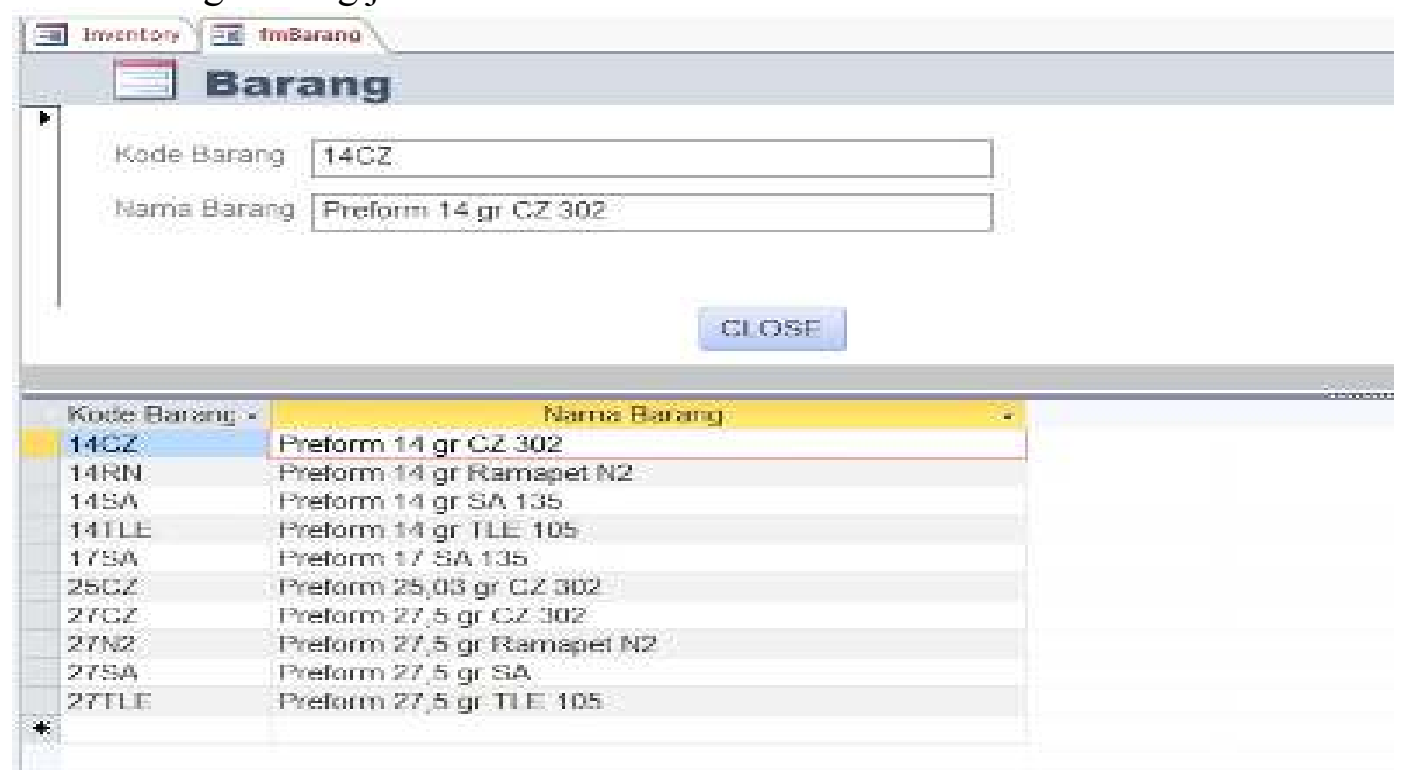

\section{Gambar 6. Menu Barang}

Menu gudang memuat data mengenai kode gudang dan nama gudang di PT Uniplastindo Interbuana Bali. Gudang bahan baku dibagi menjadi 2 areal yaitu gudang A dan gudang B. Gudang A kemudian dibagi lagi menjadi beberapa kode baris yaitu Gudang A1-A13 dan Gudang B1-B16. 
Penginputan data akan dilakukan ketika ada material masuk dan material yang keluar dari gudang. Dalam sistem yaitu di menu data masuk dan data keluar. Menu data masuk memuat data yaitu tanggal material yang masuk ke dalam gudang, kode barang, jumlah yang masuk dan lokasi penempatan didalam gudang berupa kode gudang.

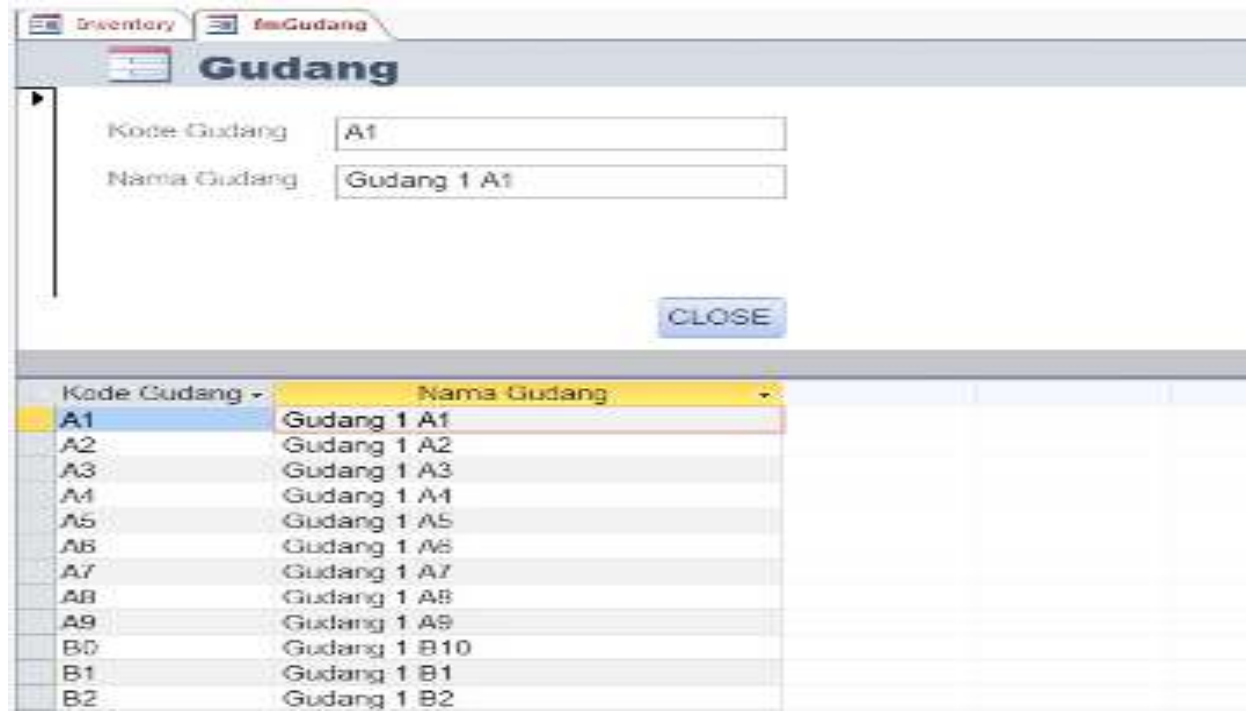

Gambar 7. Menu Gudang

Menu data keluar memuat data yang sama seperti data masuk namun diperuntukkan untuk barang yang keluar dari gudang. Kedua menu tersebut telah dibuat sinkron, sehingga ketika menginputkan data masuk, maka jumlah data akan bertambah, dan ketika mengeluarkan material di data keluar maka data material akan berkurang dari sistem.

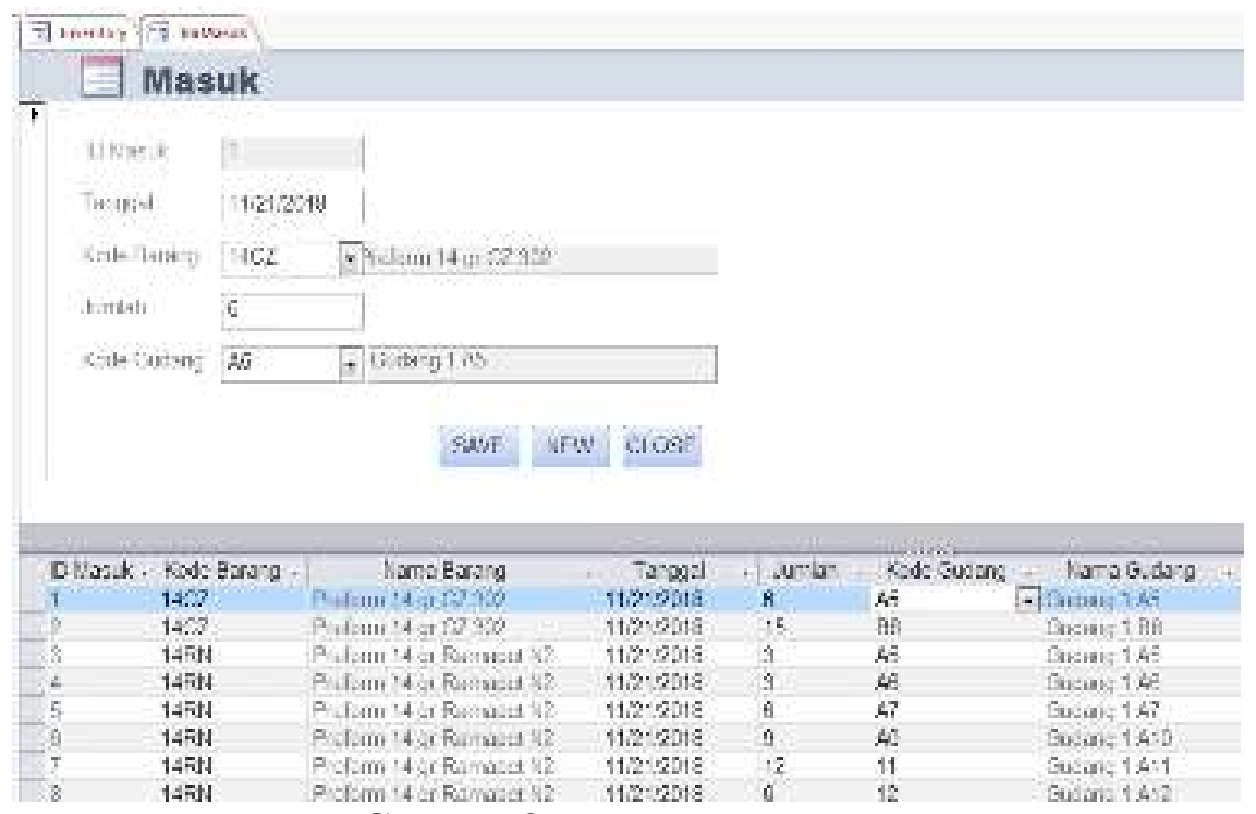

Gambar 8. Menu Data Masuk 


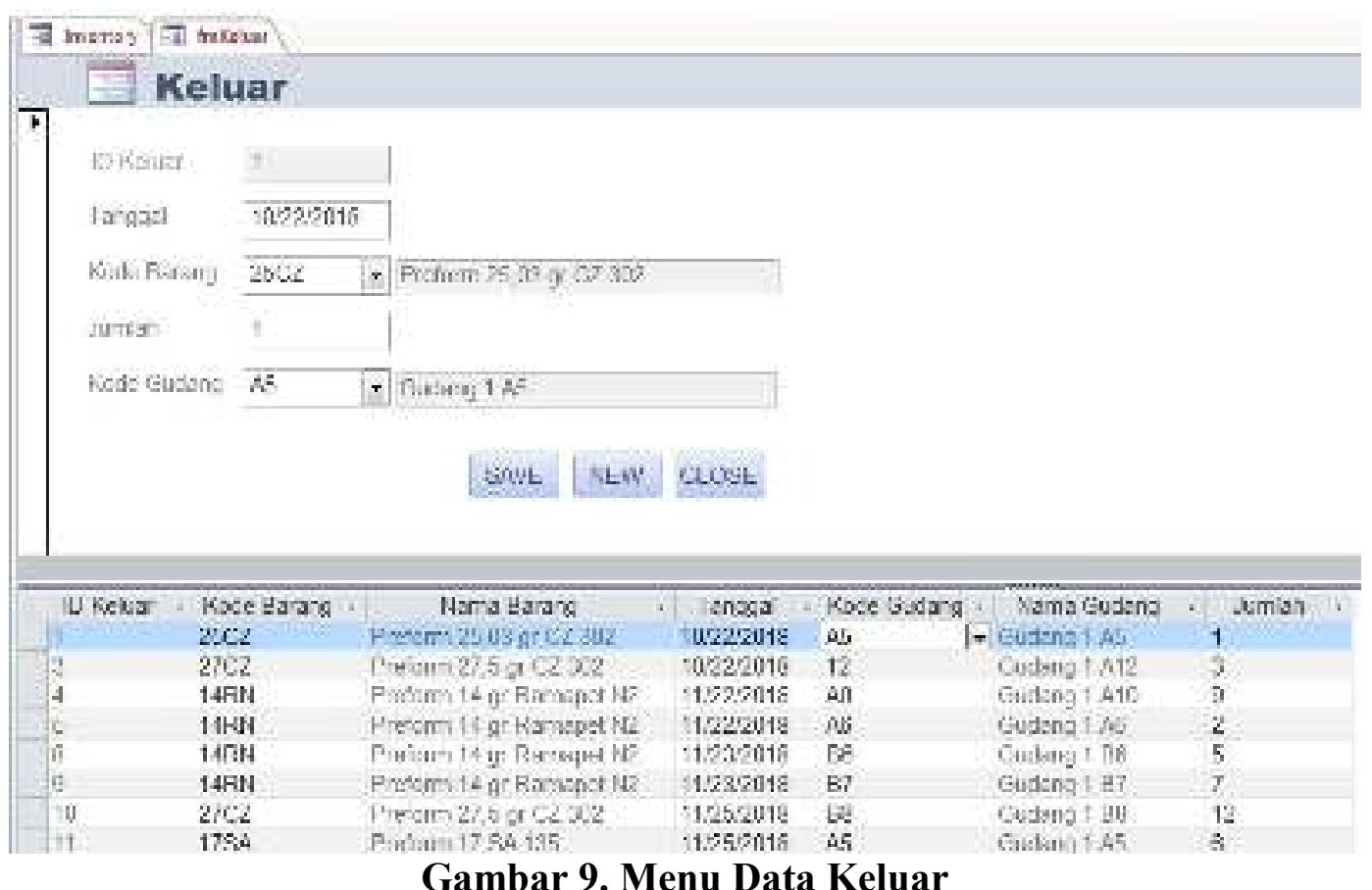

Setelah data diinputkan baik data masuk maupun data keluar maka dapat dilihat data stok akhir material di dalam gudang. Stok akhir dapat dilihat dalam menu stock akhir. Data akan ditunjukkan berupa kode barang, nama barang dan jumlah stock akhir di dalam sistem.

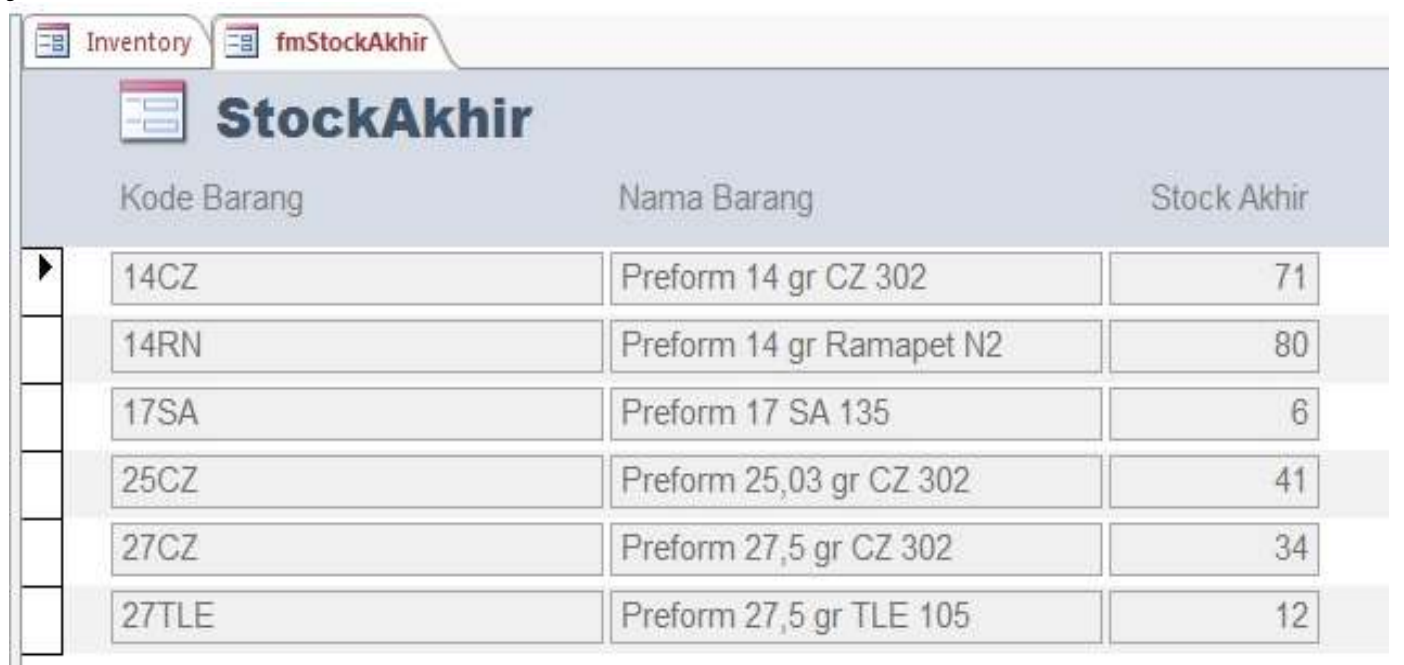

\section{Gambar 10. Menu Stock Akhir}

Menu stock kode barang dan stock kode gudang adalah laporan stock akhir berdasarkan kode barang dan kode gudang. Stock kode barang menunjukkan jumlah stock akhir dalam sistem dengan acuan kode barang, sedangkan stock kode gudang acuan stock adalah kode gudang, sehingga akan memudahkan dalam pencarian material. 


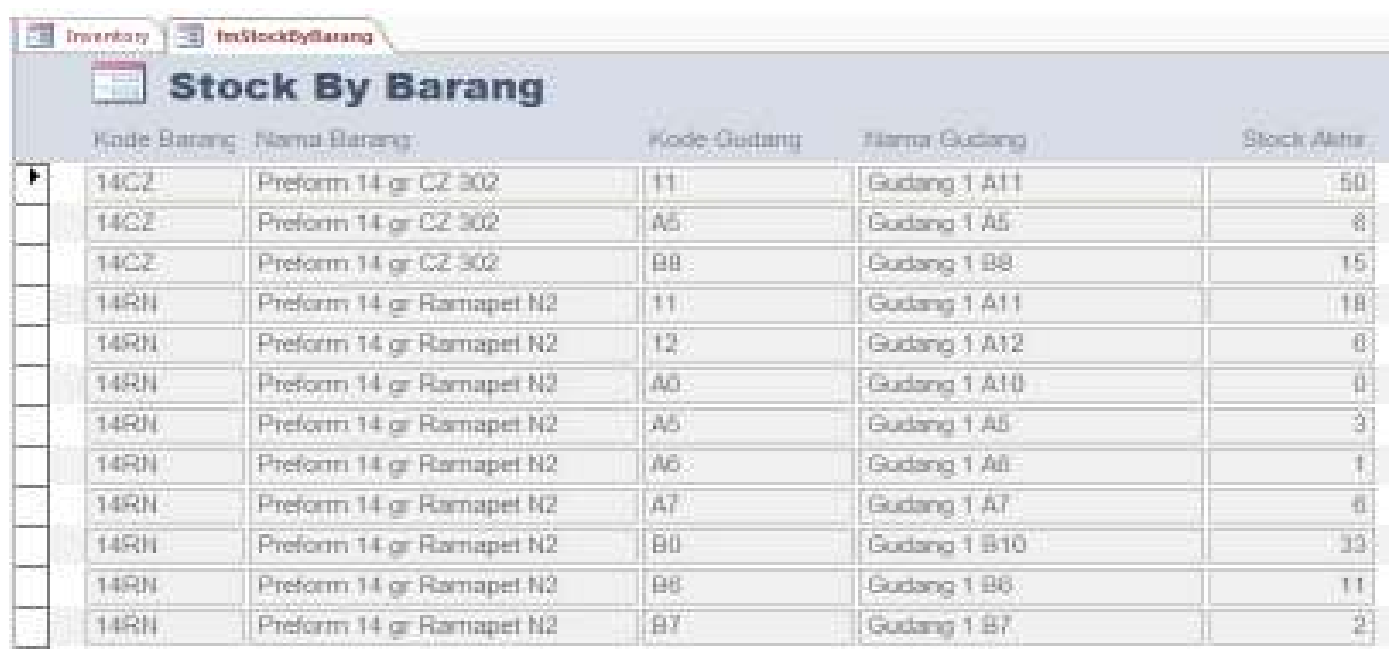

Gambar 11. Menu Stock Kode Barang

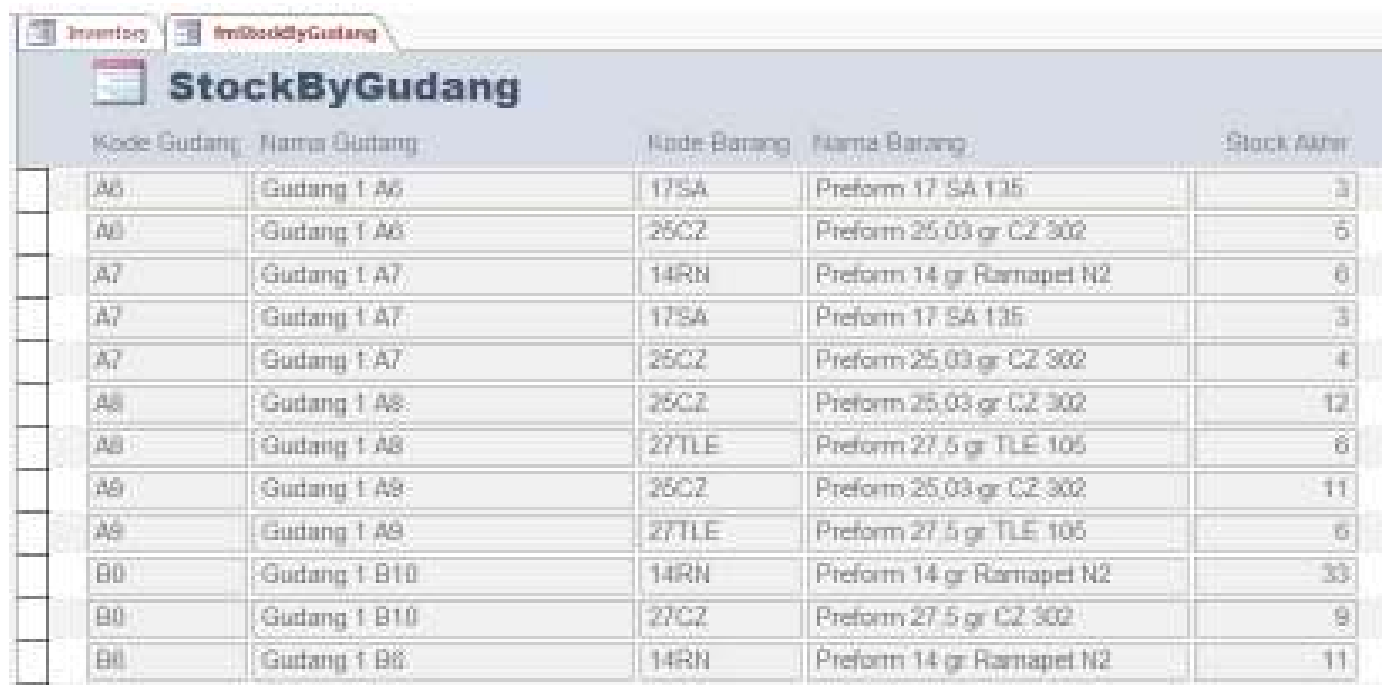

Gambar 12. Menu Stock Kode Gudang

Biaya pengadaan aplikasi database dapat ditentukan untuk melihat seberapa efisien penerapannya didalam perusahaan. Aplikasi yang digunakan yaitu berupa sistem database sederhana berupa software Ms. Access. Pembuatannya menggunakan desain manual yang menentukan query atau hubungan dari masingmasing data. Pengadaan desain dalam bentuk aplikasi ini mengabiskan biaya kurang lebih $\mathrm{Rp}$ 500.000. Sehingga biaya pengadaan aplikasi yang perlu dipertimbangkan oleh perusahaan yaitu sebesar Rp 500.000.

Pengumpulan data dan simulasi dilakukan dengan melibatkan operator forklift dan admin PPIC. Proses pengambilan data dilakukan pada kegiatan peneriman dan pengiriman material. Berikut adalah tahapan dalam kegiatan simulasi.

Pengecekan jadwal sehubungan dengan penerimaan material yang datang sesuai dengan jadwal kedatangan. Material preform terjadwal paling cepat setiap hari sekali dan paling lambat dua minggu sekali. Jadwal kedatangan material dapat bervariasi yang disebabkan oleh jumlah stok baik di perusahaan maupun di supplier 
atau jika terjadi kendala dalam perjalanan karena material dipasok dari Pulau Jawa. Sedangkan untuk jadwal pengiriman material ke bagian produksi dilakukan setiap pagi hari.

Persiapan peralatan dan perlengkapan untuk kegiatan simulasi dilakukan sebelumnya. Peralatan yang digunakan yaitu satu buah notebook merek Asus dengan sistem warehousing pada Microsoft Access untuk penginputan data dan Stopwatch untuk menghitung jumlah waktu perpindahan material. Perlengkapan yang digunakan untuk tambahan pencatatan yaitu berupa buku catatan dan pulpen.

Kegiatan pengumpulan data dilakukan pada saat kegiatan pengiriman dan penerimaan material preform. Pengiriman preform dilakukan setiap pagi hari antara pukul 07.00 Wita - 08.00 Wita. Sedangkan penerimaan material dilakukan setiap kedatangan dari supplier sekitar pukul 10.00 Wita atau pukul 14.00 Wita. Simulasi melibatkan serta operator forklift sesuai dengan pembagian shift setiap harinya. Jumlah pengiriman dan penerimaan preform yang akan diambil data dibuat sama agar memudahkan dalam perhitungan biaya. Jumlah yang akan dihitung adalah sebanyak 10 oktabin yang dipindahkan.

Pengumpulan data sebelum dilakukannya simulasi yaitu dengan menghitung jumlah waktu yang dibutuhkan untuk melakukan penerimaan dan pengiriman material. Durasi waktu dihitung dengan menggunakan stopwatch dan kemudian dicatatkan. Proses pengumpulan data seperti ini dilakukan selama 7 hari. Setelah data terkumpul maka kegiatan selanjutnya adalah pengumpulan data dengan simulasi.

Sebelum simulasi dilakukan di lapangan, data mengenai jumlah, tanggal produksi, dan lokasi material di gudang 1 akan di-input terlebih dahulu ke dalam sistem. Data diperoleh melalui data harian admin PPIC terkait stok real material. Simulasi akan dilakukan berangkat dari data terakhir mengenai jumlah material dan lokasi penempatan. Pengiriman material dilihat dari bon order dari admin produksi yang telah diterima oleh operator forklift. Jenis barang yang diorder kemudian dicari dari sistem. Tanggal produksi disesuaikan dengan sistem FIFO (First In First Out) dalam hal ini digunakan tanggal produksi sebagai acuan, sehingga material dengan tanggal produksi terlama akan dikeluarkan terlebih dahulu. Setelah lokasi material tersebut ditemukan dan jumlahnya sesuai maka proses pengiriman siap dilakukan. Proses mulai dari pengambilan material pertama hingga material terakhir akan dihitung waktunya menggunakan stopwatch.

Setelah proses pengiriman material berakhir maka akan dilakukan update data dalam sistem yaitu pengurangan material yang telah dikirimkan. Pengurangan jumlah serta menarik dari lokasi semula sehingga data dalam sistem akan sama dengan aktual stok yang ada dalam gudang material.

Proses penerimaan material juga memiliki langkah yang hampir sama dimana operator forklift akan ditunjukkan mengenai data dengan update terakhir. Melalui data sistem akan dilihat area dan kolom mana yang dapat diisi dengan material baru. Setelah area ditentukan maka proses bongkar dari kontainer supplier dilakukan. Satu persatu palet diturunkan dan diletakkan pada area kosong di dalam gudang. Setelah seluruh material diletakkan di dalam gudang maka langkah selanjutnya adalah menginput data ke dalam sistem. Data berupa jenis material, jumlah material 
yang diterima, tanggal poduksi material serta lokasi penempatan material di dalam gudang akan dimasukan ke dalam sistem agar stok bertambah.

Hasil data baik pengurangan dan penambahan material juga akan diserahkan kepada admin PPIC. Data tersebut digunakan untuk update laporan harian kepada manajemen serta sebagai acuan mengenai order material kepada supplier.

Tabel 3.

Hasil Pengukuran Data Pengiriman Material Preform Sebelum Simulasi WMS selama Bulan Oktober - November 2018

\begin{tabular}{ccccc}
\hline $\begin{array}{c}\text { Hari } \\
\text { ke- }\end{array}$ & $\begin{array}{c}\text { Jumlah } \\
\text { material } \\
\text { (oktabin) }\end{array}$ & $\begin{array}{c}\text { Jumlah Waktu } \\
\text { (menit.detik) }\end{array}$ & $\begin{array}{c}\text { Rata-rata Waktu per } \\
\text { Pengiriman Material } \\
\text { (menit.detik) }\end{array}$ & $\begin{array}{c}\text { Jarak Tempuh } \\
\text { (meter) }\end{array}$ \\
1 & 10 & $27.03,59$ & $05.24,72$ & 720 \\
2 & 10 & $24.01,38$ & $04.48,28$ & 714 \\
3 & 10 & $25.43,84$ & $05.08,76$ & 714 \\
4 & 10 & $27.35,46$ & $05.31,09$ & 718 \\
5 & 10 & 23.15 .33 & $04.39,06$ & 710 \\
6 & 10 & 24.23 .60 & $04.52,72$ & 712 \\
7 & 10 & $26.24,17$ & $05.16,83$ & 718 \\
Total & $\mathbf{7 0}$ & $\mathbf{2 . 5 8 . 2 7 , 3 7}$ & & $\mathbf{5 . 0 0 6}$ \\
\hline Sumber: Data observasi, 2018 & & &
\end{tabular}

Tabel 4.

Hasil Pengukuran Data Penerimaan Material Preform Sebelum Simulasi WMS selama Bulan Oktober - November 2018

\begin{tabular}{ccccc}
\hline $\begin{array}{c}\text { Hari } \\
\text { ke- }\end{array}$ & $\begin{array}{c}\text { Jumlah } \\
\text { material } \\
\text { (oktabin) }\end{array}$ & $\begin{array}{c}\text { Jumlah Waktu } \\
\text { (menit.detik) }\end{array}$ & $\begin{array}{c}\text { Rata-rata Waktu per } \\
\text { Penurunan material } \\
\text { (menit.detik) }\end{array}$ & $\begin{array}{c}\text { Jarak Tempuh } \\
\text { (meter) }\end{array}$ \\
1 & 10 & $25.02,89$ & 04.20 .06 & 162 \\
2 & 10 & $28.30,56$ & 05.02 .07 & 167 \\
3 & 10 & $27.04,75$ & $05.40,43$ & 166 \\
4 & 10 & $26.43,12$ & $05.19,31$ & 166 \\
5 & 10 & $28.54,61$ & $05.23,06$ & 169 \\
6 & 10 & $28.02,93$ & $05.48,29$ & 170 \\
7 & 10 & $35.31,64$ & $07.06,16$ & 172 \\
Total & $\mathbf{7 0}$ & $\mathbf{3 . 1 9 . 5 0 , 5 0}$ & & $\mathbf{1 . 1 7 2}$ \\
\hline
\end{tabular}

Sumber: Data observasi, 2018

Tabel 5.

Hasil Pengukuran Data Pengiriman Material Preform saat Simulasi WMS selama Bulan Oktober - November 2018

\begin{tabular}{ccccc}
\hline $\begin{array}{c}\text { Hari } \\
\text { ke- }\end{array}$ & $\begin{array}{c}\text { Jumlah material } \\
\text { (oktabin) }\end{array}$ & $\begin{array}{c}\text { Total Waktu } \\
\text { (menit.detik) }\end{array}$ & $\begin{array}{c}\text { Rata-rata Waktu per } \\
\text { Pengiriman Material } \\
\text { (menit.detik) }\end{array}$ & $\begin{array}{c}\text { Jarak Tempuh } \\
\text { (meter) }\end{array}$ \\
1 & 10 & $22.05,63$ & $04.40,63$ & 714 \\
2 & 10 & $23.01,79$ & $04.30,29$ & 716 \\
3 & 10 & $19.43,83$ & $03.55,96$ & 704 \\
4 & 10 & $23.35,46$ & $04.43,09$ & 711 \\
5 & 10 & 18.15 .33 & $03.39,07$ & 700 \\
6 & 10 & 21.23 .60 & $04.03,93$ & 706 \\
7 & 10 & $22.24,17$ & $04.44,03$ & 709 \\
Total & $\mathbf{7 0}$ & $\mathbf{2 . 3 0 . 2 9 , 8 1}$ & & $\mathbf{4 . 9 6 0}$ \\
\hline Sumber: Data observasi, 2018 & &
\end{tabular}


Tabel 6.

Hasil Pengukuran Data Penerimaan Material Preform saat Simulasi WMS selama Bulan Oktober - November 2018

\begin{tabular}{ccccc}
\hline $\begin{array}{c}\text { Hari } \\
\text { ke- }\end{array}$ & $\begin{array}{c}\text { Jumlah } \\
\text { material } \\
\text { (oktabin) }\end{array}$ & $\begin{array}{c}\text { Jumlah Waktu } \\
\text { (menit.detik) }\end{array}$ & $\begin{array}{c}\text { Rata-rata Waktu per } \\
\text { Penurunan material } \\
\text { (menit.detik) }\end{array}$ & $\begin{array}{c}\text { Jarak Tempuh } \\
\text { (meter) }\end{array}$ \\
1 & 10 & $22.50,71$ & $04.45,63$ & 158 \\
2 & 10 & $23.62,78$ & $04.50,27$ & 161 \\
3 & 10 & $25.34,70$ & $05.06,47$ & 164 \\
4 & 10 & $22.54,83$ & $04.17,48$ & 160 \\
5 & 10 & $29.48,60$ & $05.56,40$ & 168 \\
6 & 10 & $24.12,34$ & $04.55,23$ & 163 \\
7 & 10 & $23.34,72$ & $04.47,08$ & 162 \\
Total & $\mathbf{7 0}$ & $\mathbf{2 . 5 2 . 5 8 , 6 8}$ & & $\mathbf{1 . 1 3 7}$ \\
\hline
\end{tabular}

Sumber: Data observasi, 2018

Tabel 7.

Jumlah Waktu dan Jarak dalam Kegiatan Observasi

\begin{tabular}{lcccc}
\hline & $\begin{array}{c}\text { Waktu } \\
\text { Pengiriman } \\
\text { Material } \\
\text { (jam.menit.detik) } \\
\text { 2.58.27,37 }\end{array}$ & $\begin{array}{c}\text { Waktu Penerimaan } \\
\text { Material } \\
\text { (jam.menit.detik) }\end{array}$ & $\begin{array}{c}\text { Total Waktu } \\
\text { (jam.menit.detik) }\end{array}$ & $\begin{array}{c}\text { Jarak } \\
\text { Tempuh } \\
\text { (meter) }\end{array}$ \\
$\begin{array}{l}\text { Sebelum } \\
\text { Simulasi WMS }\end{array}$ & $3.19 .50,50$ & $6.18 .17,57$ & 6.178 \\
$\begin{array}{l}\text { Saat Simulasi } \\
\text { WMS }\end{array}$ & $2.30 .29,81$ & $2.52 .58,68$ & $5.23 .28,49$ & 6.097 \\
\hline Sumber: Data observasi, 2018 & & &
\end{tabular}

Tabel 8.

Penggunaan Bahan Bakar Gas LPG selama Bulan Juni - November 2018

\begin{tabular}{lccccc}
\hline Bulan & $\begin{array}{c}\text { Jumlah } \\
\text { Penggunaan } \\
\text { (tabung) }\end{array}$ & $\begin{array}{c}\text { Harga } \\
\text { per Item } \\
\text { (Rp) }\end{array}$ & $\begin{array}{c}\text { Total } \\
\text { Harga (Rp) }\end{array}$ & $\begin{array}{c}\text { Rata-rata } \\
\text { penggunaan per } \\
\text { Hari (Rp) }\end{array}$ & $\begin{array}{c}\text { Biaya per } \\
\text { Jam dari } \\
\text { Rata-rata } \\
\text { per Hari } \\
\text { (Rp) }\end{array}$ \\
Juni & & & & & 2.938 \\
Juli & 15 & 135.000 & 2.025 .000 & 67.500 & 2.938 \\
Agustus & 16 & 135.000 & 2.160 .000 & 72.000 & 2.938 \\
September & 16 & 135.000 & 2.160 .000 & 72.000 & 2.938 \\
Oktober & 15 & 135.000 & 2.025 .000 & 67.500 & 2.938 \\
November & 15 & 135.000 & 2.025 .000 & 67.500 & 2.938 \\
Rata-rata & 17 & 135.000 & 2.295 .000 & 76.500 & \\
\hline Sumber: PT Unips & & & &
\end{tabular}

Sumber : PT Uniplastindo Interbuana Bali, 2018

Perhitungan frekuensi perpindahan diperoleh dengan menjumlahkan palet yang dipindahkan pada saat material keluar dan masuk ke gudang. Jumlah perpindahan material untuk observasi dibuat sama agar dapat memudahkan perhitungan dan perbandingan data. Dalam sekali perpindahan material, forklif mampu mengangkut maksimal sebanyak 2 oktabin material preform, dan pengukuran dilakukan terhadap 5 kali perpindahan, sehingga total material yang dilakukan pengukurannya adalah sebanyak 10 oktabin pertama yang dipindahkan. 
Total perpindahan material setiap kegiatan pengiriman dan penerimaan material setiap harinya yaitu 10 palet $/$ hari $x 7$ hari $=70$ palet.

Pengukuran jarak saat pengiriman material dihitung jarak antara tempat pengambilan material di gudang bahan baku sampai dengan penempatan di areal produksi. Sedangkan untuk pengukuran jarak saat penerimaan material yaitu jarak antara material saat diturunkan dari kontainer sampai dengan tempat penyimpanan di gudang bahan baku. Berdasarkan Tabel 7 didapat data yaitu jarak tempuh material saat sebelum simulasi yaitu 6.178 meter dan jarak tempuh material saat simulasi yaitu 6.097 meter. Jarak total adalah jarak keseluruhan pergerakaan material didalam gudang. Perhitungan jarak total dilakukan dengan mengukur jarak antara titik pusak blok keluar masuk dengan titik pusat blok penyimpanan. Jarak total didapat dengan menentukan titik pusat penyimpanan di gudang dan titik pusat penyimpanan di areal produksi serta areal loading. Jarak total antara gudang penyimpanan dan areal produksi adalah 140 meter atau $140 \mathrm{~m} / 2$ palet. Maka jarak keseluruhan yaitu $140 \mathrm{~m} / 2$ palet $\times 70$ palet $=4.900$ meter. Jarak total antara gudang penyimpanan dan loading penerimaan adalah 32 meter atau $32 \mathrm{~m} / 2$ palet. Maka jarak keseluruhan yaitu $32 \mathrm{~m} / 2$ palet x 70 palet $=2.240$ meter Maka didapat jarak totalnya adalah $4.900 \mathrm{~m}+2.240 \mathrm{~m}=7.140 \mathrm{~m}$

Peralatan yang digunakan pada proses material handling yaitu forklift dengan data yaitu harga perolehan (HP) forfklift yaitu sebesar Rp 275.000.0000,- (jumlah 1 unit). Umur ekonomis forklift $=25$ tahun dengan nilai sisa (residu) forklift $=\mathrm{Rp}$ $8.000 .000,00$. Biaya maintenance atau pemeliharaan forklift setiap bulannya adalah sebesar Rp 725.400,00 atau sebesar Rp 24.180/hari. Maka biaya sebelum dan saat simulasi adalah $\mathrm{Rp} 24.180 \times 7$ hari $=\mathrm{Rp}$ 96.720. Biaya depresiasi dihitung menggunakan depresiasi garis lurus dengan hari operasional alat angkut yaitu 345 hari dalam satu tahun. Biaya sebelum dan saat simulasi adalah Rp 30.956 × 7 hari $=\mathrm{Rp}$ 216.692. Bahan bakar yang digunakan untuk alat angkut forklift yaitu gas LPG. Gas LPG yang digunakan adalah gas LPG Pertamina berukuran $12 \mathrm{~kg}$. Harga untuk satu buah gas LPG $12 \mathrm{~kg}$ yang digunakan adalah Rp 135.000,00. Berdasarkan Tabel 8 penggunaan bahan bakar dalam satu hari dirata-ratakan yaitu sebesar Rp 70.500,00/hari selama bulan Juni-November 2018. Berdasarkan rata-rata harian didapat biaya perjamnya yaitu sebesar Rp 2.938,00/jam. Pada Tabel 7 jumlah waktu sebelum simulasi yaitu 6 jam 18 menit 17,87 detik. Maka biaya bahan bakar yaitu sebagai berikut $(\operatorname{Rp} 2.938 / 1$ jam x 6 jam $)+(\operatorname{Rp} 2.938 / 60$ menit x 18 menit $)+(R p$ $2.938 / 3600$ detik $\times 17,87$ detik) $=R p 18.5238$ ). Jumlah waktu saat simulasi yaitu 5 jam 23 menit 28,49 detik. Maka biaya bahan bakar yaitu (Rp 2.938/1 jam x 5 jam $)+(\operatorname{Rp} 2.938 / 60$ menit $\times 23$ menit $)+(\operatorname{Rp} 2.938 / 3600$ detik x 28,49 detik $)=\mathrm{Rp}$ 15.839. Biaya operator forklift dihitung berdasarkan upah operator per jam dan waktu operasional forklift. Perusahaan dalam hal ini menerapkan upah sebagai biaya tetap atau upah tetap bulanan. Upah/gaji bulanan yang diterima oleh seorang operator forklift adalah sebesar Rp 2.239.387 atau Rp 74.646/hari. Maka biaya operator forklift sebelum dan saat simulasi adalah Rp 74.646 x 7 hari $=$ Rp 522.522

Ongkos material handling $(\mathrm{OMH})$ sebelum simulasi WMS adalah sebagai berikut. Total biaya = biaya maintenance + biaya depresiasi + biaya bahan bakar + biaya operator. Total biaya $=\operatorname{Rp} 96.720+\operatorname{Rp} 216.692+\operatorname{Rp} 18.523+\operatorname{Rp} 522.522$ $=\mathrm{Rp} 854.457$. Total jarak tempuh $=6.178 \mathrm{~m}$ dan jarak total $=7.140 \mathrm{~m}$. Sehingga 
ongkos material handling $(\mathrm{OMH})=\mathrm{Rp} 854.457 / 7.140 \mathrm{~m} \times 6.178 \mathrm{~m}=\mathrm{Rp} 739.333$. Ongkos material handling $(\mathrm{OMH})$ saat simulasi WMS adalah sebagai berikut. Total biaya = biaya maintenance + biaya depresiasi + biaya bahan bakar + biaya operator. Total biaya $=\operatorname{Rp} 96.720+\operatorname{Rp} 216.692+\mathrm{Rp} 15.839+\mathrm{Rp} 522.522=\mathrm{Rp} 851.773$. Total jarak tempuh $=6.097 \mathrm{~m}$ dan jarak total $=7.140 \mathrm{~m}$. Sehingga ongkos material handling $(\mathrm{OMH})=\mathrm{Rp} 851.773 / 7.140 \mathrm{~m} \times 6.097 \mathrm{~m}=\mathrm{Rp} 727.347$.

Hasil perhitungan berdasarkan data sebelum dan setelah simulasi didapat total OMH sebelum simulasi adalah sebesar Rp 739.333 dan total OMH setelah simulasi adalah sebesar Rp 727.347. Berdasarkan hasil perhitungan tersebut dapat dilihat adanya perbedaan biaya yaitu sebesar Rp 11.986. Perbedaan biaya tersebut yang ditimbulkan dari penerapan sistem warehousing.

Munculnya efisiensi biaya tersebut dikarenakan sistem yang dibuat membantu dalam penentuan lokasi secara spesifik material yang diperlukan. Sehingga hal tersebut dapat membantu mempermudah operator dalam pengambilan material di gudang. Operator dapat dengan mudah menemukan material yang dibutuhkan dan tidak membuang banyak waktu dalam proses pencarian. Selain itu, penggunaan sistem warehousing juga sangat mampu untuk meningkatkan efisiensi kerja bagi admin PPIC. Admin yang setiap harinya harus melakukan perhitungan dan pencatatan persediaan material lebih dimudahkan dengan adanya sistem warehousing ini.

Perhitungan persediaan dan pencatatan manual yang dilakukan biasanya menghabiskan waktu selama 30 menit. Saat ini hanya perlu melakukan update data dalam waktu 5 menit, maka data aktual dilapangan dapat dimiliki oleh admin. Hal lain yang perlu dipertimbangkan oleh perusahaan adalah biaya pengadaan aplikasi (software). Jumlah besaran biaya yang diperlukan untuk pengadaan sistem adalah minimal Rp 500.000. Biaya tersebut akan disesuaikan lagi dengan kebutuhan perusahaan karena sistem yang digunakan untuk kegiatan simulasi adalah berupa sistem sederhana. Sehingga apabila perusahaan menginginkan sistem yang lebih kompeten maka biaya pengadaannya akan lebih besar.

Berdasarkan hasil penelitian yang disimpulkan diatas ternyata terdapat pengaruh penerapan sistem warehousing dengan Microsoft Access terhadap efisiensi perusahaan. Sehingga dapat diimplikasikan warehouse management system dapat dapat dijadikan masukan, bahan pertimbangan, serta referensi dalam mengambil kebijakan-kebijakan bagi pihak perusahaan PT Uniplastindo Interbuana Bali untuk dapat menerapkan sistem pergudangan secara paten. Tidak hanya untuk gudang material, melainkan juga untuk gudang produk jadi.

Hasil penelitian ini menyadarkan perusahaan untuk senantiasa berkembang mengikuti perkembangan teknologi. Kecanggihan teknologi saat ini tentunya akan banyak memberikan perubahan yang positif bagi perusahaan. Pengelolaan teknologi serta pengembangan sistem yang tepat akan dapat meningkatkan efisiensi bagi perusahaan yang tujuan utamanya adalah meningkatkan pendapatan.

\section{SIMPULAN}

Berdasarkan pembahasan hasil penelitian yang telah dilakukan, maka dapat diambil kesimpulan yaitu Penerapan warehouse management system dengan sistem sederhana untuk simulasi berupa software Ms. Access menunjukkan bahwa 
penerapan sistem dapat meningkatkan efisiensi biaya material handling. Hal ini dilihat dari jumlah ongkos material handling sebelum simulasi sebesar Rp 739.333 dan ongkos material handling setelah simulasi sebesar Rp 727.347 sehingga timbul selisih sebesar Rp 11.986. Selisih tersebut yang menunjukkan adanya efisiensi biaya yang dihasilkan dalam penerapan sistem warehousing.

Penerapan warehouse management system juga dapat memberikan kemudahan bagi admin dalam mengumpulkan data karena dengan adanya sistem data dapat dikumpulkan dengan lebih mudah, cepat dan akurat. Berdasarkan kesimpulan penelitian dan implikasi hasil penelitian yang penulis kemukakan diatas, maka penulis dapat memberikan beberapa saran yang diharapkan dapat berguna bagi semua pihak. Adapun saran-saran tersebut antara lain Penerapan warehouse management system menunjukkan adanya efisiensi terhadap proses penanganan material serta pengumpulan data, maka dari itu dapat disarankan kepada perusahaan untuk dapat menerapkan sistem secara resmi.

Penggunaan sistem secara resmi pada perusahaan harus dapat mempertimbangkan beberapa hal seperti pemahaman terhadap admin dan juga operator mengenai keseriusan dalam pengumpulan data. Hal tersebut karena sistem memerlukan update setiap kali adanya keluar masuk material sehingga data yang terdapat dalam sistem adalah data aktual. Hasil penelitian ini juga dapat dimanfaatkan oleh perusahaan untuk pengembangan aplikasi khususnya pada sistem pergudangan serta umumnya untuk proses bisnis keseluruhan sesuai dengan kebutuhan perusahaan.

\section{REFERENSI}

Al-Shakarchy, \& Noor, D. K. (2015). Warehouse Management System. International Journal of Science Dan Research (IJSR), 4(10), 1-20.

Alyahya, S., Wang, Q., \& Bennett, N. (2016). Application and Integration of an RFID-enabled Warehousing Management System - A Feasibility Study. Journal of Industrial Information Integration, 1(1), 1-12.

Azizi, A., Al-Humairi, A., \& Yazdi, P. G. (2018). Design and Fabrication of Intelligent Material Handling System in Modern Manufacturing with Industry 4.0 Approaches. International Robotics \& Automation Journal, 4(3), 1-10.

Bagir, M. H., \& Putro, B. E. (2018). Analisis Perancangan Sistem Informasi Pergudangan di CV. Karya Nugraha. Jurnal Media Teknik Dan Sistem Industri, 2(1), 20-29.

Chow, H. K. ., Choy, K. L., Lee, W. B., \& Lau, K. C. (2016). Design of a RFID Case-Based Resource Management System for Warehouse Operations. Journal Expert Systems with Applications: An International Journal, 30(4), 561-576.

Faber, N. (2013). Organizing Warehouse Management. International Journal of Operation \& Production Management, 33(9), 12-40.

Gomes, C. F. S., Cabral, P. C., \& Freire, K. A. (2016). Warehouse Management System: A Bibliometric Study. Research Gate, 1(1), 1-35. 
Hakim, Z., Setiawan, \& Yanatris, Y. A. (2017). Perancangan Sistem Informasi Penempatan Barang Jadi Pada Departemen Gudang Finish Goods. Jurnal Sisfotek Global, 7(1), 1-20.

Koster, R. B. M. D., Johnson, A. L., \& Roy, D. (2017). Warehouse Design And Management. International Journal of Production Research, 55(21), 63276330 .

Kusuma, E. F. (2017). Perbaikan Manajemen Pergudangan Plant B di PT XYZ. Jurnal Tirta, 5(2), 211-218.

Kusuma, Y., Sumarauw, J. S. B., \& Wangke, S. J. C. (2017). Analisis Sistem Manajemen Pergudangan Pada CV. Sulawesi Pratama Manado. Jurnal EMBA, $5(2), 602-611$.

Lee, C. K. ., Lv, Y., Ng, K. K. H., Ho, W., \& Choy, K. L. (2017). Design and Application of Internet of Thing-Based Warehouse Management System for Smart Logistic. International Journal of Production Research, 1(4), 190-206.

Leopatria, M., \& Palit, H. C. (2013). Perancangan Sistem Manajemen Gudang Tepung di PT X. Jurnal Tirta, 1(2), 49-56.

Lukman, \& Sunoto, I. (2016). Rancang Bangun Aplikasi Warehouse Management System CV. Giyanmandiri. Jurnal String, 1(2), 1-10.

Mahendradipa, L. E. (2013). Sistem Informasi Pendistribusian Barang Melalui Transporter pada PT Tiga Pilar Semarang. Jurnal Sistem Informasi, 1(1), 111.

Maheswari, H., \& Dany, A. (2015). Evaluasi Tata Letak Fasilitas Produksi untuk Meningkatkan Efisiensi pada PT Nusa Multilaksana. Jurnal Ilmiah Manajemen Dan Bisnis, 1(3), 1-14.

Makisurat, A., Elim, J. M., \& Inggriani. (2014). Penerapan Sistem Pengendalian Intern untuk Persediaan Barang Dagangan Pada CV. Multi Media Persada Manado. Jurnal EMBA, 2(2), 1151-1161.

Ogbo, A. I., Ukpere, W. I., \& Victoria, O. I. (2014). The Impact of Effective Inventory Control Management on Organisational Performance: A Study of 7 up Bottling Company Nile Mile Enugu, Nigeria. Mediterranean Journal of Social Sciences, 5(10), 109-118.

Permadi, R. W., \& Setya, Y. A. (2014). Evaluasi Pencatatan Sistem Pergudangan Pada Koperasi Hikmah Pacitan. Speed Journal, 11(4), 1-20.

Prabowo, A. R., \& Pujotomo, D. (2017). Penerapan Software Open ERP Modul Warehouse Management Pada Gudang Mustika Ratu di Semarang. Industrial Engineering Online Journal, 6(1), 1-20.

Pradana, A. (2013). Pembangunan Sistem Informasi Pengendalian dan Perencanaan Persediaan Bahan Baku di CV Maika Mandiri Sejahtera. Jurnal Ilmiah Komputer Dan Informatika (Komputa), 5(1), 1-9. 
Prayodya, C. A., \& Rinawati, D. I. (2017). Implementasi Software ERP Odoo 8 di Warehouse PT Apparel One Indonesia Semarang. Jurnal Industrial Engineering, 6(2), 1-12.

Ramaa., K. N. S., \& Rangaswamy, T. M. (2012). Impact of Warehouse Management System in a Supply Chain. International Journal of Computer Applications, 54(1), 1-20.

Scavarda, L. F., Baros, M., Jose, A., Reyes, P. M., \& Jaska, P. (2012). Warehouse Management System Implementation in a Brazilian Distributor Center. International Journal of Operation Research and Information System, 3(2), 64-76.

Singh, M. B., \& Singh, N. T. (2015). Analysis of Inventory Management of Selected Plastic Industries in Manipur. The International Journal of Business \& Management, 3(1), 1-29.

Tamas, P., Dobos, P., \& Illes, B. (2017). Examination of Improvement Possibilities in Warehouse Management System. Logistic Journal, 1(2), 1-23.

Wahyudi, R. (2015). Analisis Pengendalian Persediaan Barang Berdasarkan Metode EOQ di Toko Era Baru Samarinda. Ejournal Ilmu Administrasi Bisnis, $2(1), 1-23$.

Wambua, B. J., Okibo, W. B., Nyang'Au, A., \& Ondieki, S. M. (2015). Effects Of Inventory Warehousing System on the Financial Performance of Seventh Day Adventist Institutions: A Case of Adventist Book Centers (ABC). International Journal of Business and Management, 10(4), 1-14.

Wiyono, D. S., Pribadi, R. P., \& Sidigdoyo. (2011). Perancangan Aplikasi Warehouse Management System Berbasis Web Service sebagai Media ELearning dalam Studi Logistik. Jurnal Rekayasa, 4(1), 1-23.

Wood, L. C., Reiners, T., \& Pahl, J. (2015). Manufacturing and Logistics Information System. Information Science and Technology, 1(2), 5136-5144. 